\title{
New Data on the distribution of Trogidae (Coleoptera, Scarabaeoidea) in the Khabarovskii krai of Russia
}

\author{
Новые данные о распространении Trogidae \\ (Coleoptera, Scarabaeoidea) в Хабаровском крае России
}

\author{
V.K. Zinchenko*, V.G. Bezborodov**, V.V. Dubatolov*, *** \\ В.К. Зинченко*, В.Г. Безбородов**, В.В. Аубатолов*, ***
}

\footnotetext{
* Institute of Systematics and Ecology of Animals, Siberian Branch of the Russian Academy of Sciences, Novosibirsk 630091 Russia. E-mail: vscar@ngs.ru.

* Институт систематики и экологии животных СО РАН, ул. Фрунзе 11, Новосибирск 630091 Россия.

** Amur Branch of Botanical Garden-Institute, Far East Branch of the Russian Academy of Sciences, Ignatevskoye Shosse, 2-nd km, Blagoveshchensk 675000 Russia. E-mail: cichrus@yandex.ru.

** Амурский филиал Ботанического сада-института ДВО РАН, 2-й км Игнатьевского шоссе, Благовещенск 675000 Россия.

*** Federal State Institution «Zapovednoe Priamurye», Yubileinaya Str. 8, Khabarovskii Krai, Bychikha 680502 Russia.

*** ФГУ «Заповедное Приамурье», ул. Юбилейная, 8, Хабаровский край, пос. Бычиха 680502 Россия.
}

Key words: Coleoptera, Scarabaeoidea, Trogidae, new localities, Khabarovskii krai, Bolshekhekhtsirskii Nature Reserve, Botchinskii Nature Reserve.

Ключевые слова: Coleoptera, Scarabaeoidea, Trogidae, новые локалитеты, Хабаровский край, Большехехцирский заповедник, Ботчинский заповедник.

\begin{abstract}
New information on the distribution of Trogidae beetles in Khabarovskii Krai is presented. Trox nohirai Nakane, 1954 is recorded for Khabarovskii Krai and the Botchinskii Nature Reserve for the first time, and T. scaber (Linnaeus, 1767) and Glyptotrox ineptus (Balthasar, 1931) are new to the Bolshekhekhtsirskii Nature Reserve.
\end{abstract}

Резюме. Приведены новые сведения о распространении Trogidae в Хабаровском крае. Trox nohirai Nakane, 1954 - впервые приводится для фауны края и Ботчинского заповедника. Trox scaber (Linnaeus, 1767) и Glyptotrox ineptus (Balthasar, 1931) впервые отмечены в Большехехцирском заповеднике.

The Trogidae family (Coleoptera, Scarabaeoidea) numbers more than 300 species, of which 87 species have been identified in the Palaearctic [Pittino, Bezděk, 2016]. There are about 20 species are known for Russia [Nikolajev, 2016], 10 species for Far East of Russia [Bezborodov, 2016], and 5 species for the Khabarovskii Krai [Bezborodov, 2014, 2017]. Many taxa are rare, so new distribution data is of considerable interest for understanding the range. For the first time, the fauna of the Khabarovskii Krai and the Botchinskii Nature Reserve is given - Trox nohirai Nakane, 1954, previously noted only in the south of the Primorskii Krai [Gusakov, 2009; Bezborodov, 2016]. Trox scaber (Linnaeus, 1767) and Glyptotrox ineptus (Balthasar, 1931) were noted firstly in the Bolshekhekhtsirskii Nature Reserve [Bezborodov, Zinchenko, 2010].

\section{Results}

Glyptotrox ineptus (Balthasar, 1931)

Fig. 1.

Material. Khabarovskii Krai: Khabarovskii District, Bolshekhekhtsirskii Nature Reserve, point Chirki, 48 $11^{\prime} \mathrm{N}$, $134^{\circ} 41^{\prime}$ E, 12-14.VII.2015, V.G. Bezborodov $-3 \mathrm{sp}$.

Distribution. Russia (East Siberia and South of the Far East), Mongolia.

Notes. New species for the fauna of the Bolshekhekhtsirskii Nature Reserve.

\section{Trox (Niditrox) nohirai Nakane, 1954}

Fig. 1.

Material. Khabarovskii Krai: Sovietsko-Gavanskii district, Sikhote-Alin, Botchinskii Nature Reserve, upper reaches Mulpa River, Spur Kamenistyi, southern slope with oak and maple, 48 $17.4^{\prime} \mathrm{N}, 139^{\circ} 31.4^{\prime} \mathrm{E}$, light trap, 5-6.VI.2017, V.V.Dubadov-1o; Ulchskii district, Lower Amur, Kiselevka, a valley broad-leaved forest, $51^{\circ} 25^{\prime} \mathrm{N}, 139^{\circ} 01^{\prime} \mathrm{E}$, light trap, 13-14.VII.2008, V.V. Dubatolov - $10^{7}$.

Distribution. Russia (Khabarovskii Krai and Primorskii Krai), Japan.

Notes. A new species for the fauna of the Khabarovskii krai and the Botchinskii Nature Reserve.

$$
\begin{gathered}
\text { Trox (Niditrox) scaber (Linnaeus, 1767) } \\
\text { Fig. } 1 .
\end{gathered}
$$

Material. Khabarovskii Krai: Bolsbekbekbtsirskii Nature Reserve, Sosninskii stream, mixed forest, $48^{\circ} 16^{\prime} \mathrm{N}$, $134^{\circ} 45.5^{\prime} \mathrm{E}, \mathrm{h} \sim 100 \mathrm{~m}$, light trap, 19-20.05.2016, 56.06.2017, V.V. Dubatolov - 3 sp. 


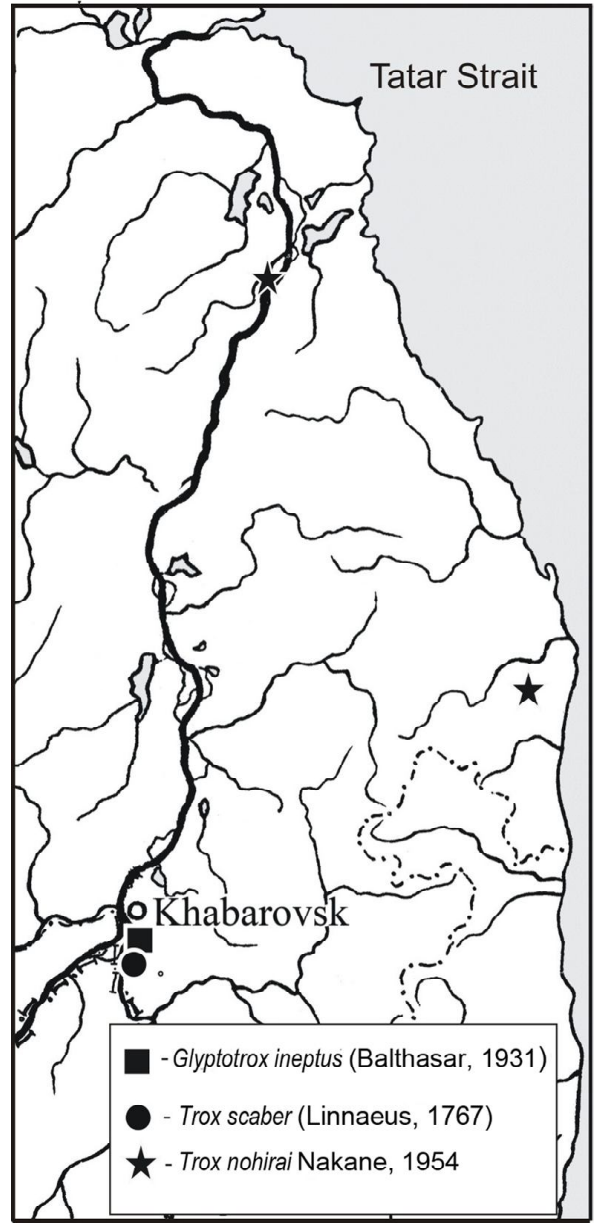

Fig. 1. New data on the distribution of Trogidae in the Khabarovskii Krai

Рис. 1. Новые данные о распространении Trogidae в Хабаровском крае
Distribution. Cosmopolitan.

Notes. New species for the fauna of the Bolshekhekhtsirskii Nature Reserve.

\section{Acknowledgements}

The study was supported by the Federal Fundamental Scientific Research Programme for 2013-2020 (AAAA-A161161214101, № VI.51.1.9).

\section{References}

Bezborodov V.G. 2014. Annotated list of the lamellicorn beetles (Coleoptera, Scarabaeoidea) of the fauna of Khabarovskii Krai (Russia) // Amurian zoological journal. Vol.6. No.2. P.125-146. [In Russian]

Bezborodov V.G. 2016. Annotated catalogue of the lamellicorn beetles (Coleoptera, Scarabaeoidea) of the Far East of Russia // Amurian zoological journal. Vol.8. No.2. P.110-153. [In Russian]

Bezborodov V.G. 2017. Lamellicorn beetle fauna (Coleoptera, Scarabaeoidea) of the Khabarovskii Krai of Russia: taxonomic structure, ecology and zoogeography // Evraziatskii Entomologicheskii Zhurnal (Euroasian Entomological Journal). Vol.16. No.5. P.432-445. [In Russian]

Bezborodov V.G., Zinchenko V.K. 2010. Lamellicorn beetles (Coleoptera, Scarabaeoidea) of Bolshekhekhtsirskii Nature Reserve and adjacent territories (Khabarovskii Krai) // Amurian zoological journal. Vol.2. No.1. P.41-49. [In Russian]

Gusakov A.A. 2009. Superfamily Scarabaeoidea // Storozhenko S.Yu. (eds.). Insects of the Lazovskii Nature Reserve. Vladivostok: Dal'nauka. P.127-131. [In Russian].

Nikolajev G.V. 2016. Taxonomic composition of the family Trogidae (Coleoptera: Scarabaeoidea) of the Russian fauna // Caucasian entomological bulletin. Vol.12. No.1. P.81-91. [In Russian].

Pittino R., Bezděk A. 2016. Family Trogidae Macleay, 1819 // Löbl, I., Löbl, D. (Eds.). Catalogue of Palaearctic Coleoptera. Vol.3. Scarabaeoidea-Scirtoidea-DascilloideaBuprestoidea-Byrrhoidea. Leiden, Boston: Brill. P.53-58. 